\title{
Elections in Nondemocratic Settings: When and Why Do They
}

\section{Help Regime Survival? [version 1; peer review: 1 approved}

\section{with reservations]}

\author{
Katsunori Seki (iD)
}

Faculty of Humanities and Social Sciences, University of Tsukuba, Tsukuba, Ibaraki, 305-8577, Japan

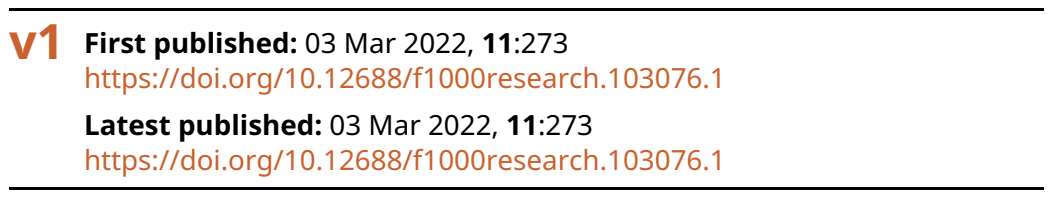

\section{Abstract}

Background: Elections in nondemocratic settings are expected to play a regime sustaining role and a regime subverting role. Recent research finds that these two seemingly competing views are not mutually exclusive, but rather complementary with each other. This is the case because the regime subverting role of elections is at work in the short run, whereas the regime sustaining role operates in the long term. In this paper, I argue that these effects are conditional on the nature of competition in those elections. Specifically, I contend that these effects that derive from the informational role of elections do not emerge when opposition forces boycott the elections. Methods: Using data from 262 nondemocratic regimes in 116 countries from 1946 to 2007, I examined (1) whether holding multiparty elections with ex ante competition increases the risks of authoritarian breakdowns; (2) whether holding multiparty elections without opposition boycott increases the risks of authoritarian breakdowns in the short term; and (3) whether holding multiparty elections without opposition boycott decreases the likelihood of authoritarian breakdowns in the long run. Results: First, only legislative elections with ex ante competition are found to increase the probability of authoritarian breakdowns. Second, both presidential and legislative elections increase the likelihood of authoritarian breakdowns in the short term only if viable opposition candidates or parties compete. Lastly, both presidential and legislative elections decrease the chances of authoritarian breakdowns in the long run, but this effect is present only when viable opposition do not boycott the elections. Conclusions : The regime subverting role and the regime sustaining role of elections in nondemocratic settings can be contaminated by the absence of opposition forces. This paper suggests a need to further scrutinize the nature and quality of elections when assessing their impact on the survival of nondemocratic regimes.

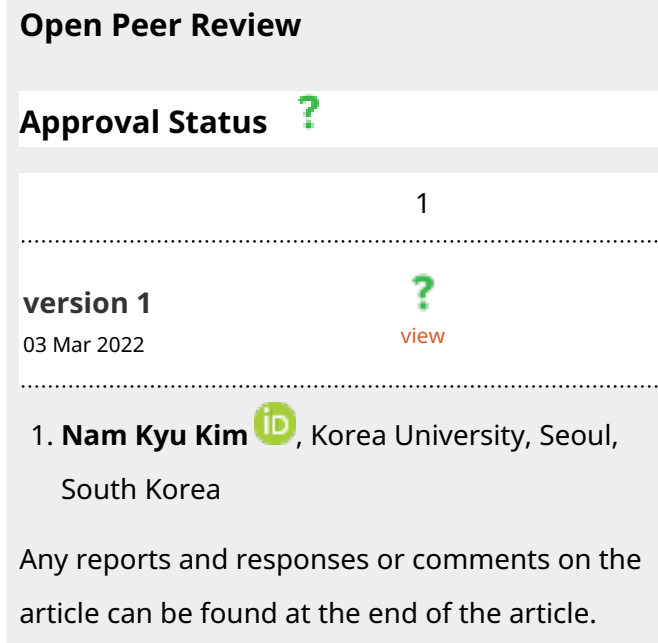




\section{Keywords}

Elections in nondemocratic settings, Informational role of elections, Regime sustaining role of elections, Regime subverting role of elections, Opposition boycott

This article is included in the Japan Institutional

\section{G JAPAN Gateway gateway.}

\section{Corresponding author: Katsunori Seki (seki.katsunori.fu@u.tsukuba.ac.jp)}

Author roles: Seki K: Conceptualization, Data Curation, Formal Analysis, Funding Acquisition, Investigation, Methodology, Project Administration, Resources, Software, Supervision, Validation, Visualization, Writing - Original Draft Preparation, Writing - Review \& Editing

Competing interests: No competing interests were disclosed.

Grant information: This work was supported by Japan Society for the Promotion of Science Grant-in-Aid for Early-Career Scientists. Grant Number: 20K13392

The funders had no role in study design, data collection and analysis, decision to publish, or preparation of the manuscript.

Copyright: $\odot 2022$ Seki K. This is an open access article distributed under the terms of the Creative Commons Attribution License, which permits unrestricted use, distribution, and reproduction in any medium, provided the original work is properly cited.

How to cite this article: Seki K. Elections in Nondemocratic Settings: When and Why Do They Help Regime Survival? [version 1; peer review: 1 approved with reservations] F1000Research 2022, 11:273 https://doi.org/10.12688/f1000research.103076.1

First published: 03 Mar 2022, 11:273 https://doi.org/10.12688/f1000research.103076.1 


\section{Introduction}

Elections in nondemocratic settings have been conducted ever since elections were inaugurated in eighteenth- and nineteenth-century Western Europe and Latin America (Gandhi and Lust-Okar, 2009). Departing from an early view that those elections play little to no substantive role in nondemocracies (e.g., Hermet, 1978), more recent studies in comparative politics, particularly since the 1990s, have theorized and found evidence for possible benefits and costs that are associated with them (e.g., Donno, 2013; Gandhi and Lust-Okar, 2009; Lindberg, 2009; Schedler, 2013). The question whether elections in nondemocratic settings play a regime sustaining role or a regime subverting role has been not only intriguing itself, but also important for professionals and activists who pursue democratic changes.

Recent studies on nondemocratic regimes and elections that are held in those regimes share the view that both roles are indeed at work, but take different forms. For instance, scholars argue that elections with ex ante competition might cause risks, but surviving elections can give fruits to dictators (Seki, 2015); elections might help dictators in the short run, but harm them in the long term (Knutsen et al., 2017); and competitive elections might entail risks, but they contribute to the life of a regime once a regime survives the first several elections and reduces electoral uncertainty (Bernhard et al., 2020). In short, these studies indicate that seemingly competing views about the regime sustaining role and the regime subverting role of elections are not mutually exclusive, but rather complementary with each other.

What is yet to be scrutinized, however, is implicit assumptions that are prevalent in previous studies. One such assumption is the premise that the role of elections are context-free or uniform. Certainly, nondemocratic regimes can influence the course of elections at different stages. Before elections, regimes might exclude viable opposition candidates, if any, from the competition by not allowing them to stand out. During elections, they might commit electoral fraud and try to manipulate the results in their favor. After the elections, they might deliver fake results or simply deny their loss to stay in power. Even though, in many cases, nondemocratic regimes take initiatives and have a great deal of influence on the course of elections, this does not mean that opposition forces are always powerless or passive. There are cases in which opposition candidates or parties cooperate and unilaterally boycott elections with a hope of undermining the legitimacy of the regime (Beaulieu, 2006).

Although opposition boycott gives electoral victory to the regime, this eventually prevents nondemocratic elections from playing certain roles. This might be the case for two reasons. First, winning the elections in the absence of opposition participation can obscure the true strength of the regime. Second, opposition boycott does not help regimes to collect information about the true strength of opposition forces, which could have been used to coopt regime outsiders (Seki, 2015). In this paper, building on the recent developments of research on the role of elections in nondemocratic settings, I argue that the regime sustaining role and the regime subverting role of elections in nondemocratic settings are indeed contingent on how the elections are played, particularly with major opposition forces. I then test my theory with a newly assembled data set on nondemocracies from 1946 to 2007.

The rest of the paper is organized as follows. First, I overview previous studies on the elections in nondemocratic settings and derive my hypotheses. Second, I explicate my empirical strategies. Third, I present the results from my empirical analyses, showing that the regime subverting effect in the short run as well as the regime sustaining effect in the long term are both conditioned by the presence and absence of major opposition forces in the electoral contest. I then discuss the implications of my findings to the literature. The last section concludes.

\section{Elections in nondemocratic settings}

Although early studies on nondemocratic regimes contend that elections in nondemocratic settings do not play a significant role in the regime survival (e.g., Hermet, 1978), scholars have theorized and found evidence for the role that those elections play with respect to the survival of nondemocratic regimes (e.g., Gandhi and Lust-Okar, 2009; Schedler, 2013). Studies argue that elections, even if they are not completely free and fair, play an informational role, helping the life of dictators and their regime.

The informational role of elections can take two different forms. First, elections play an information gathering role. That is, elections reveal the geographic distribution of support for and opposition to the regimes. This information is then used to shape effective and efficient strategies to (re)distribute goods and patronage to sustain the regimes (Lust-Okar, 2008). Second, elections also play an information communication role. If dictators win elections with a huge margin, this will signal the invincibility of their regime (Brownlee, 2007; Simpser, 2013). Similarly, elections with a high turnout can indicate that there is little to no latent support for opposition parties and candidates that might be mobilized, which signals public acquiescence (Geddes et al., 2018). Therefore, even though elections are deemed an institution that is central to make democracies work, they can also be used to help the survival of nondemocratic counterparts. 
Despite these possible benefits of holding multiparty elections in nondemocratic settings, other scholars also point to the risks associated with conducting multiparty elections. This is the case because elections might introduce uncertainty in outcomes if they are partly free and fair (Schedler, 2013). On the one hand, election results in which incumbent dictators win with a wide margin in a presidential election and/or their party dominates its seat share in legislative elections certainly signal the invincibility of the regime (Gandhi and Lust-Okar, 2009). On the other hand, however, if opposition parties are deemed viable and demonstrate a real chance of victory in the near future, they can damage the perception of invincibility, which signals the weakness of the regime (Donno, 2013). Therefore, multiparty elections in nondemocratic settings might play a regime subverting role by rendering nondemocratic regimes vulnerable and unstable (Huntington, 1991; Przeworski, 1991).

More recently, research seems to settle this debate over pros and cons of elections in nondemocratic settings. Scholars argue that elections with ex ante competition might cause risks, but surviving elections can give fruits to dictators (Seki, 2015). Elections might help dictators in the short run, but harm them in the long term (Knutsen et al., 2017). Competitive elections might entail risks, but they contribute to the life of a regime once a regime survives first several elections and reduces electoral uncertainty (Bernhard et al., 2020). In brief, these studies indicate that seemingly competing arguments about the regime sustaining role and the regime subverting role of elections are not mutually exclusive, but rather complementary with each other.

Even though this new perspective certainly helps improve our understandings about the effect of multiparty elections in nondemocratic settings, in this paper I argue that there might be factors that possibly condition the regime sustaining role of elections, but have been overlooked in the past cross-national studies. Specifically, I suggest that election boycott by opposition parties is likely to contaminate the informational role of elections.

First, the information gathering role might not be at work when major opposition forces are not present in the elections. This can happen if major or all opposition parties unilaterally boycott the elections, even though this is not easy for them (Beaulieu, 2006). What is problematic for the regime is that, even though dictators and their allies can easily win the elections in the absence of viable oppositions, these elections provide little to no meaningful information about where true regime support and opposition exist (Seki, 2015). Thus, strategies for cooptation might not be as effective and efficient as rulers want. Put differently, the information gathering role of elections in nondemocratic settings is disabled if oppositions boycott the elections.

Second, the information communication role of elections can also be marred if opposition forces successfully boycott the elections. First, opposition boycott inflates the votes and seats that incumbent dictators and their allies receive. The augmented vote and seat share is obvious in the eyes of citizens since opposition boycott is public knowledge. This leads to the situation where, despite the overwhelming victory at ballot box, dictators fail to signal the invincibility of the regime. Moreover, latent support and opposition to the regime are not revealed through the elections. Hence, opposition boycott, if this is done successfully, also obscures the information communication role of elections.

The above discussion leads to the following hypotheses that I am going to examine in the following section:

First, consistent with past research, I expect that multiparty elections in nondemocratic settings increase the probability of authoritarian breakdown.

\section{- $H_{1}$ : General electoral uncertainty}

Holding multiparty elections increases the risks of authoritarian breakdown.

Second, although I also expect that multiparty elections in nondemocracies have both a short-term and long-term effects (e.g., Knutsen et al., 2017), I argue that the effects depend on the way in which electoral competition occurs.

\section{- $H_{2}$ : Conditional short-term regime subverting role of elections}

Holding multiparty elections, albeit limited, increases the risks of authoritarian breakdown in the short term. However, this effect manifests only when opposition parties compete in those elections. 


\section{- $H_{3}$ : Conditional long-term regime sustaining role of elections}

Communicating invincibility of regime through election results deters future challenge from dissidents, and therefore decreases the likelihood of authoritarian breakdown in the long run. However, this effect is at work only when opposition parties compete in those elections.

In the next section, I detail my empirical strategy and show the results from my analyses that cover 262 nondemocratic regimes in 116 countries from 1946 to 2007.

\section{Methods}

Study design

To test the hypotheses presented above, I construct a dataset of nondemocratic regimes from 1946 to 2007 that includes 4,256 regime-years. The dependent variable is authoritarian breakdown which is coded as " 1 " if a nondemocratic regime collapses and "0" otherwise. The data on regime breakdowns are obtained from Geddes et al. (2014). The reason for using this dataset is that it provides the start date and end date of nondemocratic regimes. Since empirical tests of the effect of individual elections on regime outcomes require high precision regarding when elections were held and when a regime began and ended, their dataset is ideal in this regard.

Following Carter and Signorino (2010), I estimated logistic regressions while including a cubic polynomial of the duration of nondemocratic regimes. The duration is counted for each nondemocratic regime, and not for the nondemocratic period in a given country that ignores changes from a nondemocracy to another nondemocracy with a different set of ruling elites. In the following analyses, standard errors are clustered by nondemocratic regimes, not by countries. Decade dummies from 1940s to 1990s are included in the model while using the 2000s as the reference category. Observations with missing values are deleted.

\section{Data collection}

Data on elections which constitute the key independent variables of this study are taken from the Varieties of Democracy (V-Dem) project. In this paper, I use version 10 of this data project (Coppedge et al., 2020). To test the first hypothesis, I employ the variable, v2elmulpar, which measures the extent to which a national election was multiparty. ${ }^{1}$ To measure whether an election allowed ex ante competition, I collapsed this variable into a dichotomous variable which takes the value of " 1 " if recoded v2elmulpar takes either " 0 " or " 1 " and competition between the incumbent and oppositions are not too constrained. Otherwise, my dichotomous variable is coded as " 0 " as there is little to no real competition in the elections. ${ }^{2}$ Since the V-Dem dataset allows users to differentiate executive (presidential) elections from legislative elections, I construct the variable on elections with ex ante competition with respect to executive elections and legislative elections separately.

To test the second and the third hypotheses, I construct dummy variables which takes the value of " 1 " if in a given year there was an executive or legislative election and "0" otherwise. Following Knutsen et al. (2017, 114), for both types of elections, I create two variables-one represents the short-term effect and another the long-term effect. Specifically, I apply a decay function which takes the following form:

$$
N_{y+t}=N_{y} * 2^{(-t / \tau)}
$$

where $y$ is the year of an election, $t$ is the number of years since that election, and $\tau$ denotes the average time it takes for the effect to halve. For the short-term effect $\tau$ is set to 1 while $\tau$ is defined as 5 for the long-term effect.

$$
\begin{aligned}
& \text { Short-term effect: } N_{y+t}=N_{y} * 2^{-t} \\
& \text { Long-term effect: } N_{y+t}=N_{y} * 2^{(-t / 5)}
\end{aligned}
$$

\footnotetext{
${ }^{1}$ I recoded this variable so that it takes the value of "4" if no party or single party and there is no meaningful competition; " 3 " if no party or single party, but multiple candidates from the same party and/or independents contest legislative seats or the presidency; " 2 " if at least one real opposition party is allowed to contest, but competition is highly constrained; "1" if elections are multiparty in principle, but either one main opposition party is prevented from contesting, or conditions such as civil unrest prevent competition in a portion of the territory; " 0 " if elections are multiparty.

${ }^{2}$ In a robustness check that I describe below, I also estimated a model that replaces the dummy variable with a continuous measure of vote/seat share in presidential/legislative elections.
} 
The variables that represent the short-term effect and the long-term effect are both coded as " 1 " in the year an election was held (i.e., $N=1$ ). In the year that follows, the short-term effect variable is coded as $1 * 2^{-1}=0.5$ and the long-term effect variable is $1 * 2^{(-1 / 5)}=0.8705 \ldots$, respectively. Two years after this election, the short-term one is now $1 * 2^{-2}=0.25$ and the long-term one is $1 * 2^{(-2 / 5)}=0.7578 \ldots$, respectively. In this way, we can assess the effect of individual elections in the short run and the long run simultaneously. These calculations continue until the next election, be it held regularly or irregularly, took place in the same regime. This means that once a new nondemocratic regime replaces an old one, the effect of an election in the previous regime stops operating. Similarly to the covariates on the existence/absence of ex ante competition defined above, I construct the short-term effect and the long-term effect variables of elections for presidential elections and legislative elections separately.

The V-Dem data also provide the measure of election boycott (v2elboycot). Conceptually, this variable is measured through a five point scale with which " 0 " means that all opposition parties and candidates boycotted the elction" while " 4 " indicates that no parties or candidates boycotted the elections. This variable is first measured as a continuous variable that ranges from 0 to 4 by using item response theory (the resulting variable is named v2elboycot_osp). Then, this continuous measure is transformed to an ordinal variable ( $v 2$ elboycot_ord). In the following analyses, I use both versions to check if the findings are sensitive to the difference in measurement techniques. Note that in the analyses below, the values of these boycott variables are reversed so that a larger value indicates a greater extent of opposition boycott. These recoded boycott variables are interacted with the short-term and long-term effect of both presidential ane legislative elections.

Analysis

Following previous studies on the survival of nondemocratic regimes, I input control variables that include subtypes of nondemocracies, natural log of GDP per capita, economic growth, a measure of dependence on oil revenue, and regional dummies. Subtypes of nondemocracies include party-based regime, personalist regime, military regime, and monarchy (Geddes et al., 2014). Personalist regimes are used as the reference category. GDP and growth data are taken from Bolt and Zanden (2013) which is the update of Maddison (2008). Oil dependence is obtained from Haber and Menaldo (2011). These three economic indicators are lagged by one year in the following analyses. Dummy variables that represent geographic regions follow the operationalization of Haber and Menaldo (2011). Those regions include Asia, Eastern Europe and Post-Soviet, Latin America, North Africa and Middle East, Subsaharan Africa, and Western Europe and North America. Western Europe and North America is the reference category. All replication files are available through Mendeley Data: Replication Data for "Elections in nondemocratic settings: When and why do they help regime survival?".

\section{Results}

Figure 1 presents results that do not include the election boycott variable and its interaction with the short-term and longterm effect variables to see whether findings from this baseline specification are consistent with the conclusions drawn

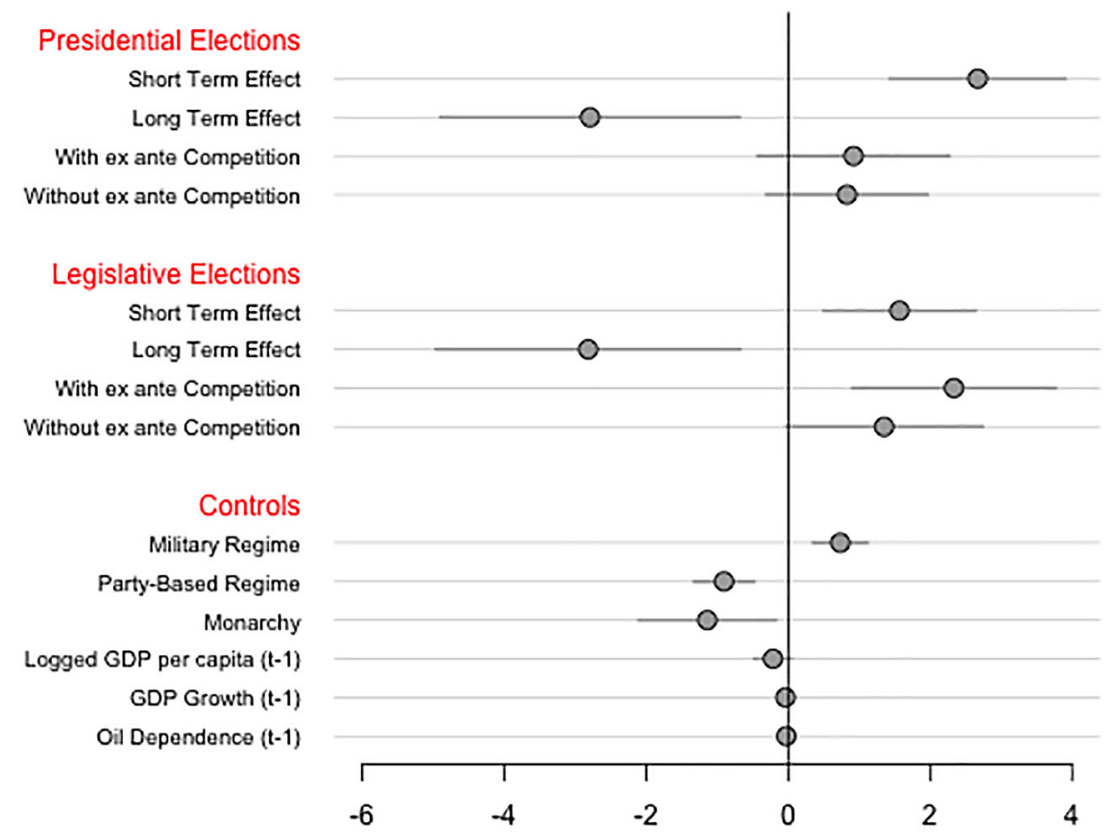

Figure 1. The baseline model. 
from previous research. The graph shows the point estimates and their $95 \%$ confidence intervals. ${ }^{3}$ Consistent with prior research, presidential elections and legislative elections both increase the likelihood of regime breakdown in the short run (the effects are statistically significant at the 0.01 level). Regarding the long-term effect of those elections, the effects are found negative and statistically significant at the 0.01 level. Military regimes are more likely to collapse and party-based regimes and monarchies are less likely to collapse than personalist regimes. While the effect of GDP per capita is not found statistically significant, economic growth and dependence on oil revenue decrease the likelihood of regime failure. In short, the analyses presented here corroborate with the findings in the literature on authoritarian breakdown.

Turning to the test of my hypotheses presented above, in the model that adds the interaction between election variables and opposition boycott, only the effect of legislative elections with ex ante competition is found positive and statistically significant at the 0.05 level. ${ }^{4}$ In other words, years in which multiparty legislative elections are held are likely to increase the risks of regime failure. Thus, the first hypothesis is partly supported by the data.

To test the second and third hypotheses, I provide the plots of marginal effect of both short-term and long-term effects of presidential and legislative elections that are contingent on the level of opposition boycott. ${ }^{5}$ Figure 2 shows the short-term effect of presidential elections on regime failure. Consistent with my expectations, the effect is positive and statistically significant only when at least some opposition candidates compete in the presidential elections (i.e., the boycott variable is smaller than or equal to 2). Likewise, Figure 3 displays the marginal short-term effect of legislative elections on regime failure. The effect is positive and significant at the 0.05 level only when a few opposition parties boycotted and they are relatively insignificant parties. In short, the regime subverting role of elections heavily depends on the presence of opposition candidates and parties in electoral contest. In the absence of viable opposition forces in the elections, the electoral uncertainty is limited so that regimes do not face challenges through the elections, at least in the short term.

Figure 4 reports the marginal long-term effect of presidential elections on the breakdown of nondemocracy. In contrast to the short-term effect, the long-term effect becomes negative and statistically significant at the 0.05 level only when major opposition candidates compete (i.e., the boycott variable ranges from 0.5 to 2). Similarly, the marginal longterm effect of legislative elections is negative and statistically significant only when viable opposition parties are present in the competition (i.e., the boycott variable is approximately greater than 0 and less than 1.5). Thus, the regime sustaining role of multi-candidate/party elections is found to be at work, again, only when viable opposition forces compete. Put

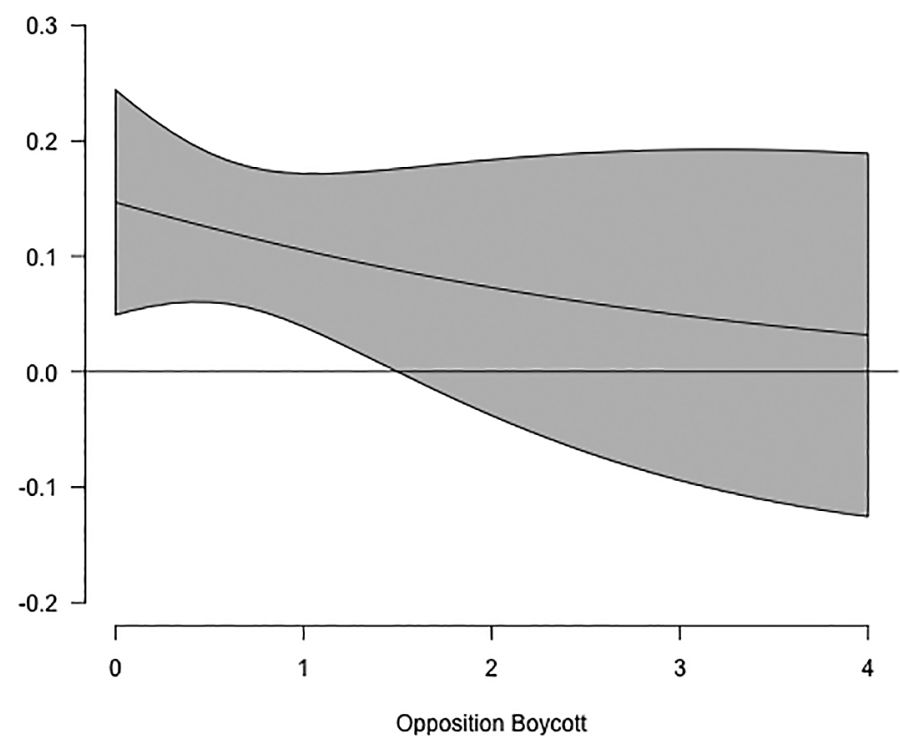

Figure 2. Marginal short-term effect of presidential elections on the breakdown of nondemocracy.

${ }^{3}$ The full results are presented in Table A1 (Column 1) in Appendix.

${ }^{4}$ The full results are presented in Table A1 (Column 2) in Appendix. The same conclusion is drawn from the baseline model in Figure 1. ${ }^{5}$ The full estimation results are available in Appendix. Here, I use the continuous measure of opposition boycott in the models. I also check if the results change when using the discrete measure of opposition boycott. Overall conclusions are not sensitive to the change in the operationalization of the boycott variables. 


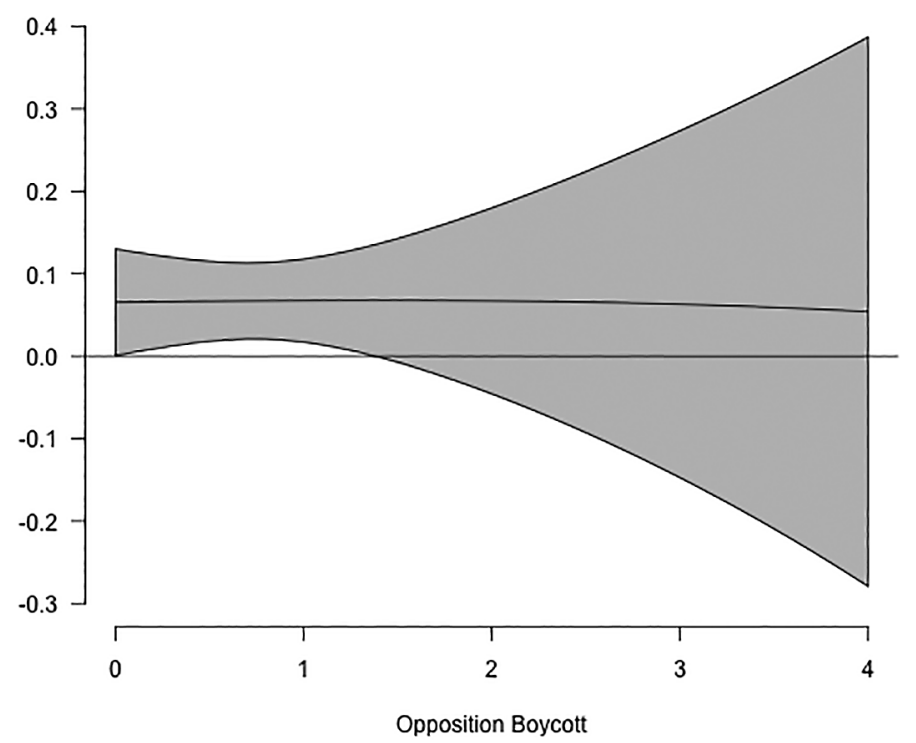

Figure 3. Marginal short-term effect of legislative elections on the breakdown of nondemocracy.

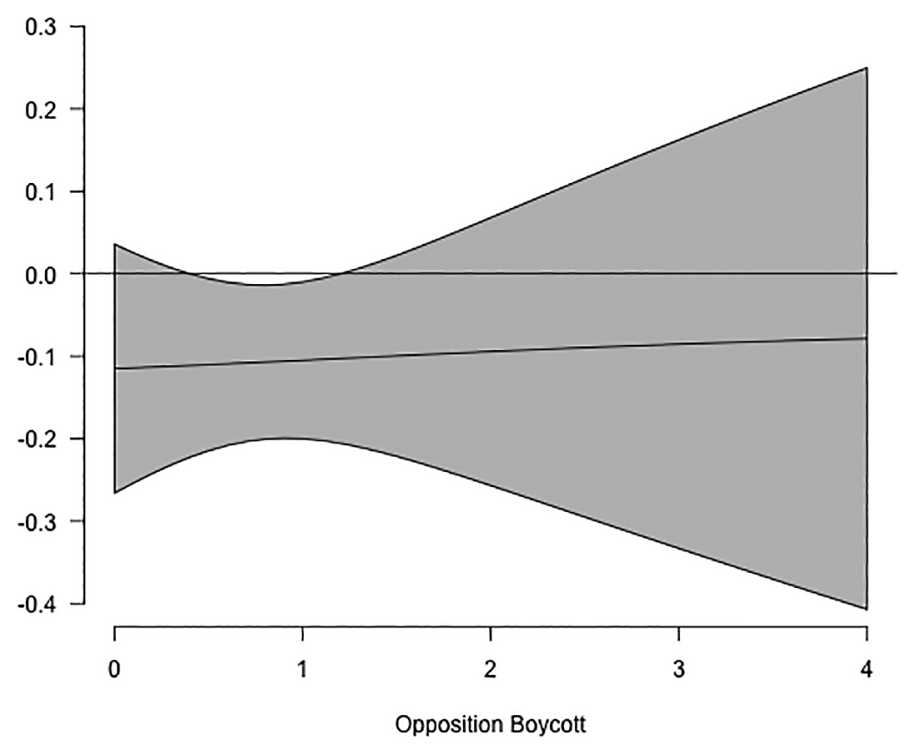

Figure 4. Marginal long-term effect of presidential elections on the breakdown of nondemocracy.

differently, the absence of opposition forces results in a noisy signal to the public. This might happen through different mechanisms. For instance, opposition boycotts lead to blurred information about the geographic distribution of support for and opposition to the regime, which makes it difficult to determine effective and efficient (re)distribution strategies for cooptation. It might also be the case that the absence of viable oppositions obscures the true invincibility of the regime because the vote and seat share of dictators and their allies are simply inflated by the election boycott.

\section{Robustness check}

First, I examine whether the way in which opposition boycott is measured has any impact on the conclusions we can draw. To address this concern, I use an alternative measure of opposition boycott which is measured as an ordinal variable. It turns out that the findings are not sensitive to the operationalization of the election boycott variable. ${ }^{6}$

${ }^{6}$ The marginal effect plots are presented in Appendix. 


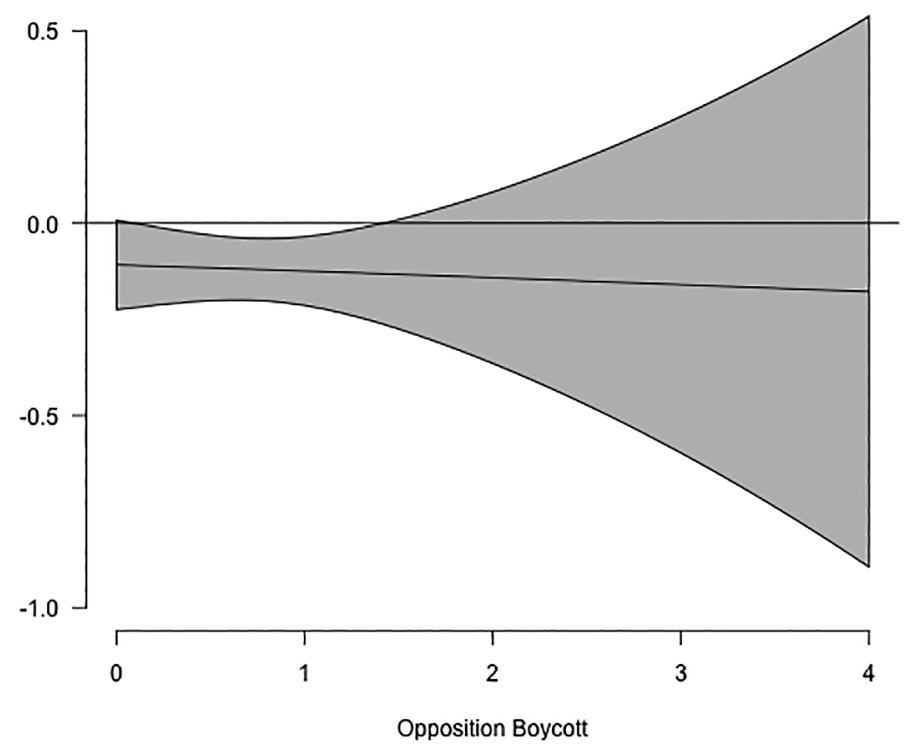

Figure 5. Marginal long-term effect of legislative elections on the breakdown of nondemocracy.

Second, the approach taken above ignores the extent to which dictators or their party perform well in the presidential and legislative elections. Using the information about how well the incumbent fares in the elections matters as the theory is concerned about the communication of invincibility of the regime. Therefore, as another robustness check, I use the vote share of the top candidate in the presidential elections and the seat share of the largest party in the legislative elections when measuring the short-term effect and the long-term effect of multi-candidate/party elections in nondemocratic settings (i.e., $N$ in the equations above are replaced with the percentage of vote/seat share in the presidential/legislative elections). In short, the overall conclusions stay unchanged. ${ }^{7}$

\section{Discussion}

The analyses presented above corroborate well with the recent findings in the literature. Specifically, I find both the regime sustaining role and the regime subverting role of elections as they are not mutually exclusive with each other. The regime subverting role is found as the short-term effect of multiparty elections while the regime sustaining role operates as the long-term effect of those elections. One advance I make in this paper, however, is the theory and the supporting evidence that these effects are contingent on the way in which elections are contested. In particular, opposition boycott disables both the regime sustaining role and the regime subverting role of elections by undermining the informational role of the elections in nondemocratic settings. Departing from this finding, it will be worth examining in the future research other factors that might affect the quality of elections to study when and why elections affect the fate of nondemocratic regimes in a systematic manner.

\section{Conclusions}

Elections in nondemocratic settings are intriguing as they seem to function in a manner different from elections in democracies. While scholars have discussed pros and cons of elections in nondemocracies with respect to the regime survival, recent studies find that those elections play a regime subverting role in the short run whereas they also play a regime sustaining role in the long run. That is, these two contrasting effects are not mutually exclusive, but are at work simultaneously. In this paper, building on this new insight in the literature, I attempt to advance our understandings about nondemocratic elections by identifying the conditions under which these effects manifest. More specifically, I argue that both effects are at work only when viable opposition forces compete in those elections. This is the case because the presence of the opposition candidates and parties is the condition under which the information gathering and communication role are activated.

Using the data on 262 nondemocratic regimes in 116 countries from 1946 to 2007, I found the evidence that supports my argument. First, years in which multiparty legislative elections were held are found to increase the probability of regime failure. Second, the short-term regime subverting role of elections is at work only when viable opposition forces compete

${ }^{7}$ The full results and the marginal effect plots are available in Appendix. 
in presidential and/or legislative elections. Likewise, the long-term regime sustaining role of elections is also present only when meaningful competition between the incumbent and oppositions exists.

This paper therefore urges future research to further scrutinize how the quality of elections might affect the effect of elections on the fate of nondemocratic regimes. It will be an intriguing next step to further scrutinize how, for instance, the variation in fairness of elections and media freedom, among many others, might condition the effect of elections on the survival of nondemocracies. By accumulating more knowledge of the role of elections in nondemocratic settings, we improve how elections help or undermine nondemocratic rule.

\section{Data availability}

Underlying data

Mendeley Data: Replication data for "Elections in nondemocratic settings: When and why do they help regime survival?" https://data.mendeley.com/datasets/p9wb86zyk2/2.

This project contains the following underlying data:

- nondem_elec_for_R.dta (Data file for replication)

\section{Extended data}

This project contains the following extended data:

- Appendix.pdf

- fig. 1 - figA9.png

- replication. R. (R script file to replicate my analyses, Tables, and Figures)

Data are available under the terms of the Creative Commons Attribution 4.0 International license (CC-BY 4.0).

\section{Acknowledgements}

An early version of this paper was presented at the conference on "The Political Economy of Democracy and Dictatorship" held at the University of Münster, Germany in February 2017. I thank discussants and floor participants for their helpful comments and suggestions.

Beaulieu E: Protesting the Contest: Election Boycotts around the World, 1990 2002 PhD thesis University of California, San Diego. 2006.

Bernhard M, Edgell AB, Lindberg SI: Institutionalising Electoral Uncertainty and Authoritarian Regime Survival. European Journal of Political Research. 2020; 59(2): 465-487.

PubMed Abstract | Publisher Full Text

Bolt J, van Zanden JL: The First Update of the Maddison Project: Re-Estimating Growth Before 1820. Maddison-Project Working Paper WP-4. 2013.

Brownlee J: Authoritarianism in an Age of Democratization. New York: Cambridge University Press; 2007.

Carter DB, Signorino CS: Back to the Future: Modeling Time Dependence in Binary Data. Political Analysis. 2010; 18(3):

271-292.

Publisher Full Text

Coppedge M, Gerring J, Knutsen CH, et al.: V-Dem [Country-Year/ Country-Date] Dataset v10. Varieties of Democracy (V-Dem) Project. 2020. Reference Source

Donno D: Elections and Democratization in Authoritarian Regimes. American Journal of Political Science. 2013; 57(3): 703-716.

Publisher Full Text

Gandhi J, Lust-Okar E: Elections under Authoritarianism. Annual Review of Political Science. 2009; 12: 403-422.

Publisher Full Text
Geddes B, Wright J, Frantz E: Autocratic Breakdown and Regime Transitions: A New Data Set. Perspectives on Politics. 2014; 12(2): 313-331.

Publisher Full Text

Geddes B, Wright J, Frantz E: How Dictatorships Work: Power, Personalization, and Collapse. Cambridge: Cambridge University Press; 2018.

Haber S, Menaldo V: Do Natural Resources Fuel Authoritarianism? A Reappraisal of the Resource Curse. American Political Science Review. 2011; 105(1): 1-26.

Publisher Full Text

Hermet G: State-Controlled Elections: A Framework. Elections without Choice. Hermet G, Rose R, editors. New York: John Wiley \& Sons; 1978; pp. 1-18.

Huntington SP: The Third Wave: Democratization in the Late Twentieth Century. Norman: University of Oklahoma Press; 1991.

Knutsen $\mathrm{CH}$, Nygård HM, Wig T: Autocratic Elections: Stabilizing Tool or Force for Change?. World Politics. 2017; 69(1):

98-143.

Publisher Full Text

Lindberg SI: The Power of Elections in Africa Revisited.

Democratization by Elections: A New Mode of Transition. Staffan I, editors.

Lindberg. Baltimore: The Johns Hopkins University Press; 2009; pp. 25-46. 
Lust-Okar E: Competitive Clientelism in Jordanian Elections. Political Participation in the Middle East. Lust-Okar E, Zerhouni S, editors. Boulder: Lynne Rienner Publishers; 2008; pp. 75-94.

Maddison A: Statistics on World Population, GDP and Per Capita GDP, 1-2006 AD. Dataset. 2008.

Przeworski A: Democracy and the Market: Political and Economic Re-forms in Eastern Europe and Latin America. Cambridge: Cambridge University Press; 1991.
Schedler A: The Politics of Uncertainty: Sustaining and Subverting Electoral Authoritarianism. Oxford: Oxford University Press; 2013.

Seki K: Causes and Consequences of Elections in Nondemocracies PhD thesis. Texas A\&M University. 2015.

Simpser A: Why Government and Parties Manipulate Elections: Theory,

Practice and Implications. Cambridge: Cambridge University Press; 2013. 


\section{Open Peer Review}

\section{Current Peer Review Status: ?}

\section{Version 1}

Reviewer Report 22 March 2022

https://doi.org/10.5256/f1000research.112728.r126220

(C) $2022 \mathrm{Kim} \mathrm{N}$. This is an open access peer review report distributed under the terms of the Creative Commons Attribution License, which permits unrestricted use, distribution, and reproduction in any medium, provided the original work is properly cited.

\section{Nam Kyu Kim}

Department of Political Science \& International Relations, Korea University, Seoul, South Korea

This study draws on recent studies on authoritarian elections and examines how election boycott by opposition parties conditions the short and long-run effects of authoritarian elections on regime survival. Specifically, it argues that election boycott by opposition parties mutes both the information gathering and the information communication roles of authoritarian elections, which stifles both regime-stabilizing and regime-destabilizing effects of elections. Looking at 262 nondemocratic regimes in 116 countries from 1946 to 2007, the paper finds that both the shortterm destabilizing effect and the long-term stabilizing effect exist only when viable opposition forces compete in elections.

I agree that the attempt to explore the contingent roles of authoritarian election is important. Election boycott by opposition parties could provide a significant context that can substantially modify the effect of authoritarian elections.

Having said that, I have two major concerns about this paper. First, I do not see any justification for the main hypotheses, $\mathrm{H}_{2}$ (Conditional short-term regime subverting role of elections) and $\mathrm{H}_{3}$ (Conditional long-term regime sustaining role of elections). I can understand that election boycott by opposition parties interferes with both the information gathering and the information communication roles of authoritarian elections. However, it is not clear to me why both regimestabilizing and regime-destabilizing effects of elections should be muted in the presence of election boycotts. Both the information gathering and the information communication roles can contribute to regime stability or survival. Then why does $\mathrm{H}_{2}$ hold true if this is the case? The author should address an additional mechanism connecting the absence of the informational role to the absence of regime-subverting role.

Additionally, the absence of the informational role of elections does not necessarily mean that elections cannot contribute to regime survival in the long run. It will only diminish the stabilizing effect since other roles remains. Here the author should further explain how election boycott by opposition parties makes other regime-stabilizing effects of authoritarian elections. 
Next, I have also concerns about empirical results. Figures 2-4 and Table $A_{1}$ in the appendix do not provide support for the author's arguments. The author shows that the short-term effect of elections on regime failure is only statistically significant when no boycott exists. This is not sufficient to support his claim. Figures 2 and 3 actually show that all marginal effects are positive, and Figure 4 shows that all marginal effects are negative. Just showing the statistical insignificance of an estimate does not demonstrate that the estimate is zero. See Rainey's AJPS (2014) article. ${ }^{1}$ Furthermore, the author should provide that the interaction effect is statistical insignificant by showing that Effect(elections | boycott) - Effect(elections | no boycott) is statistically different from zero.

\section{References}

1. Rainey C: Arguing for a Negligible Effect. American Journal of Political Science. 2014; 58 (4): 10831091 Publisher Full Text

Is the work clearly and accurately presented and does it cite the current literature? Yes

Is the study design appropriate and is the work technically sound? Yes

Are sufficient details of methods and analysis provided to allow replication by others? Yes

If applicable, is the statistical analysis and its interpretation appropriate? Partly

Are all the source data underlying the results available to ensure full reproducibility? Yes

Are the conclusions drawn adequately supported by the results? Partly

Competing Interests: No competing interests were disclosed.

Reviewer Expertise: comparative politics; authoritarian politics

I confirm that I have read this submission and believe that I have an appropriate level of expertise to confirm that it is of an acceptable scientific standard, however I have significant reservations, as outlined above. 
The benefits of publishing with F1000Research:

- Your article is published within days, with no editorial bias

- You can publish traditional articles, null/negative results, case reports, data notes and more

- The peer review process is transparent and collaborative

- Your article is indexed in PubMed after passing peer review

- Dedicated customer support at every stage

For pre-submission enquiries, contact research@f1000.com 